\title{
Prevalence of idiopathic osteosclerosis in the mandible: a cone beam computed tomography study
}

\author{
- Mojdeh Mehdizadeh Department of Oral and Maxillofacial Radiology, Dental Implants Research Center, Dental \\ Research Institute, School of Dentistry, Isfahan University of Medical Sciences, Isfahan, Iran • Farnoush Firoozi \\ Students' Research Committee, School of Dentistry, Isfahan University of Medical Sciences, Isfahan, Iran \\ - Parisa Soltani Department of Oral and Maxillofacial Radiology, Dental Implants Research Center, Dental \\ Research Institute, School of Dentistry, Isfahan University of Medical Sciences, Isfahan, Iran
}

ABSTRACT | Objective: The aim of this study is to determine the prevalence of idiopathic osteosclerosis (IO) in the mandible in an Iranian subpopulation using cone beam computed tomography (CBCT). Methods: This cross-sectional study was performed on all CBCT images obtained in 2010-2014 from the archive of Oral and Maxillofacial Radiology Department at Isfahan Dental School. Images were evaluated by two observers in identical room and monitoring conditions. IO was defined as homogenous radiopacities with no particular etiology, ranging from $2 \mathrm{~mm}$ to $2 \mathrm{~cm}$ in size. Demographic information of all patients, as well as the lesion's number, location, border, shape, and association with adjacent teeth were recorded. Results: From 377 CBCT images, 43 images (11.4\%) had at least one IO lesion. Two separate IO lesions were detected in six patients; therefore, 49 IO lesions were found in total. No gender differences were observed in IO prevalence $(\mathrm{P}=0.806)$. Although most common in patients who were in their $30 \mathrm{~s}$, IO prevalence was not statistically different among age groups $(\mathrm{P}=0.369)$. IO was most frequent in the molar region, with $63.2 \%$ of lesions. Conclusion: IO prevalence was $11.4 \%$ in the studied population and was not statistically different between age groups or sexes. Most lesions were found in the mandibular molar region.

DESCRIPTORS | Idiopathic Osteosclerosis; Mandible; Prevalence; Cone Beam Computed Tomography.

RESUMO | Prevalência de osteosclerose idiopática em ossos da mandíbula: estudo de tomografia computadorizada de feixe cônico - Objetivo: Este estudo busca determinar a prevalência de osteosclerose idiopática (OI) na mandíbula em uma subpopulação iraniana usando tomografia computadorizada de feixe cônico (TCFC). Métodos: Este estudo transversal foi conduzido em todas as imagens de TCFC obtidas entre 2010 e 2014 do arquivo do Departamento de Radiologia Oral e Maxilo-facial da Isfahan Dental School. As imagens foram avaliadas por dois observadores em condições iguais de ambiente e monitoramento. A OI foi definida como radiopacidades homogêneas sem causa específica, de tamanho entre $2 \mathrm{~mm}$ e $2 \mathrm{~cm}$. As informações demográficas de todos os pacientes foram registradas, assim como o número, localização, borda e formato da lesão e sua relação com dentes adjacentes. Resultados: De 377 imagens de TCFC, 43 imagens $(11,4 \%)$ tiveram pelo menos uma lesão de OI. Duas lesões individuais de OI foram detectadas em seis pacientes; assim, houve 49 lesões no total. A prevalência de OI não demonstrou preferência por gênero $(\mathrm{P}=\mathrm{0}, 806)$. A OI foi mais comum em pacientes na faixa dos 30 anos de idade, mas sua prevalência não diferiu estatisticamente entre faixas etárias $(P=0,369)$. A região mais comum para OI foi a do molar, onde ocorreram $63,2 \%$ das lesões. Conclusão: A prevalência de OI foi de 11,4\% na população estudada e não diferiu estatisticamente entre faixas etárias e sexos. A maioria das lesões foi encontrada na região do molar mandibular.

DESCRITORES | Osteosclerose Idiopática; Mandíbula; Prevalência; Tomografia Computadorizada de Feixe Cônico.

CORRESPONDING AUTHOR | • Parisa Soltani School of Dentistry, Isfahan University of Medical Sciences - Hezar-Jarib Ave., Isfahan, Iran • 81746-73461 E-mail: p.soltani@dnt.mui.ac.ir

- Received 07 28, 2021 • Accepted 11 17, 2021

- Dol http://dx.doi.org/10.11606/issn.2357-8041.clrd.2021.188906 


\section{INTRODUCTION}

Idiopathic osteosclerosis (IO) is a term used to describe radiopacities of unknown etiology that are incidentally found in radiographs. ${ }^{1}$ IO lesions are always asymptomatic and not associated with inflammation, dysplasia, neoplasm, or systemic diseases. Cortical expansion is also excluded. ${ }^{1,2}$ IO is mostly well-defined, prevalent in the premolar and molar regions of the mandible, and unrelated to the presence or absence of teeth. However, it can blend with the normal trabecular bone. Moreover, no radiolucent capsule is seen around lesions. ${ }^{3}$ Lesions can be round, oval, or irregular. They are usually sized between $2 \mathrm{~mm}$ and $2 \mathrm{~cm}$, but large lesions can affect the entire mandibular body. ${ }^{4}$ IO rarely causes self-limiting root resorption or displaces and hinders tooth eruption. ${ }^{3}$

Several theories have been proposed for the cause of idiopathic osteosclerosis. According to studies, IO has a developmental origin and can arise as a variation of normal bone architecture in areas with localized abundant blood supply. ${ }^{1,5,6}$ Other studies suggest a localized or systemic reactive origin for IO, such as mild inflammation and trauma after replacement of deciduous teeth with permanent dentition.7,8 Moreover, heavy occlusal forces may be associated with periapical IO. ${ }^{9}$ IO is prevalent in patients with colorectal cancer, multiple adenomatosis, and sickle cell anemia. ${ }^{10}$ Histologically, trabecular bone expands with smaller and fewer bone marrow spaces. ${ }^{11}$

The aim of this study is to determine the prevalence of IO in an Iranian subpopulation using cone-beam computed tomography (CBCT).

\section{MATERIALS AND METHODS}

\section{Study design}

This cross-sectional study was performed on all CBCT images from the archive of the Oral and Maxillofacial Radiology Department at Isfahan Dental School. The Ethics Committee of Isfahan
University of Medical Sciences has approved this study (\#383938). Images were obtained between 2010 and 2014 with the Galileos CBCT scanner (Sirona, Bensheim, Germany) using $85 \mathrm{kVp}, 21 \mathrm{mAs}$, $15 \mathrm{~cm} \times 15 \mathrm{~cm}$ or $15 \mathrm{~cm} \times 8 \mathrm{~cm}$ field of view, and $0.280 \mathrm{~mm}$ voxel size. All images obtained of the entire mandible were included in the study.

\section{Image analysis}

Images were analyzed by two observers (an oral and maxillofacial radiologist with 20 years of experience, and a trained senior dental student) in identical room and monitoring conditions. IO was defined as homogenous radiopacities with no particular etiology, sized between $2 \mathrm{~mm}$ and $2 \mathrm{~cm}$. If the observers disagreed, the senior researcher's remarks were considered.

Images were first studied in panorama view for IO detection. Cross-sectional and sagittal images were used to further confirm the presence of IO. Demographic data of patients with IO was recorded as well as number, location, border and shape of lesions and their association with adjacent teeth. Moreover, we also observed that lesions were associated with the mandibular canal and buccal and lingual cortices.

\section{Statistical analysis}

Data was entered in a Statistical Package for the Social Sciences software (SPSS, version 23, IBM, NY, USA). Descriptive analysis, kappa analysis, chi-square test, and t-test were used for statistical analysis. Level of significance was set at $\alpha=0.05$.

\section{RESULTS}

Kappa value was 0.95 for interobserver agreement in IO detection in images, indicating excellent agreement. Among 377 CBCT images, 43 images (11.4\%) had at least one IO lesion. Two separate IO lesions were detected in six patients; therefore, 49 IO lesions were found in total. Regarding patients 
with IO, $53.5 \%$ were female and $46.5 \%$ were male. Moreover, IO was prevalent in patients who were in their 30 s (Table 1). However, IO prevalence had no gender differences $(\mathrm{P}=0.806)$ and was not statistically different among age groups $(\mathrm{P}=0.369)$. The mean age of patients with IO was $47.7 \pm 16.16$, which was not statistically different from that of patients without IO (47.5 $\pm 13.66, \mathrm{P}=0.935)$.

TABLE 1 | Distribution of IO to different age groups.

\begin{tabular}{|c|c|c|}
\hline Age groups & $\begin{array}{c}\text { With I0 } \\
\text { Number (percentage) }\end{array}$ & $\begin{array}{c}\text { Without I0 } \\
\text { Number (percentage) }\end{array}$ \\
\hline 21-30 years & $7(11.7 \%)$ & $53(88.3 \%)$ \\
\hline $31-40$ years & $8(13.8 \%)$ & $50(86.2 \%)$ \\
\hline $41-50$ years & $8(9.6 \%)$ & $75(90.4 \%)$ \\
\hline $51-60$ years & $14(12 \%)$ & $103(88 \%)$ \\
\hline $61-70$ years & $3(6.1 \%)$ & $46(93.9 \%)$ \\
\hline $70+$ years & $3(30 \%)$ & $7(70 \%)$ \\
\hline IO: idiopathic osteosclerosis. & \\
\hline Total $49(100 \%)$ & \\
\hline
\end{tabular}

Idiopathic osteosclerosis was prevalent in the molar region, with $63.2 \%$ of lesions (Table 2). Lesions were contiguous with the borders of the mandibular canal in $38.8 \%$ of cases (Figure 1). Moreover, $83.7 \%$ of lesions were well-defined, whereas $16.3 \%$ of them had blending borders. Lesions were round in $47 \%$ of cases, irregular in $35 \%$, and oval in $18 \%$. Most lesions were not attached to cortical plates (34.7\%) (Table 3 ) and were sized between $3 \mathrm{~mm}$ and $10 \mathrm{~mm}$ (73.5\%), whereas $18.4 \%$ were $2-3 \mathrm{~mm}$, and $8.2 \%$ were larger than $10 \mathrm{~mm}$. IO lesions were mostly found in edentulous sites (59.2\%). About $28.6 \%$ of lesions were attached to apices of teeth and $12.2 \%$ were not.

TABLE 2 | Distribution of 10 in regions of the mandible.

\begin{tabular}{|c|c|}
\hline Location & Number (percentage) \\
\hline Incisive & $4(8.2 \%)$ \\
\hline Canine & $2(4.1 \%)$ \\
\hline Premolar & $12(24.4 \%)$ \\
\hline Molar & $31(63.2 \%)$ \\
\hline
\end{tabular}

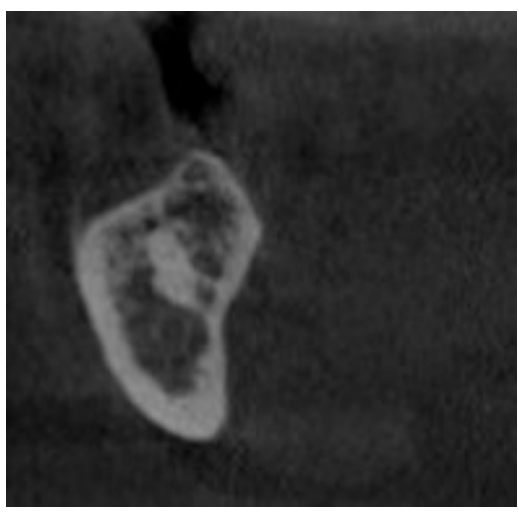

FIGURE 1 | Cross-sectional cone beam computed tomography view of idiopathic osteosclerosis in the mandible close to the borders of inferior alveolar canal.

TABLE 3 | Distribution of IO based on relation with cortices.

\begin{tabular}{|l|c|}
\hline \multicolumn{1}{|c|}{ Relation with cortices } & Number (percentage) \\
\hline Separate from cortical bone & $17(34.69 \%)$ \\
\hline Attached to buccal cortex & $11(22.44 \%)$ \\
\hline Attached to lingual cortex & $14(28.58 \%)$ \\
\hline Attached to both cortices & $7(14.28 \%)$ \\
\hline Total & $49(100 \%)$ \\
\hline
\end{tabular}

\section{DISCUSSION}

Prevalence of idiopathic osteosclerosis in the mandible reportedly ranges from $3.3 \%$ to $33 \% .^{3,5,12-14}$ This prevalence is affected by the applied radiographic modality of choice or by the studied population. In our study, IO prevalence was $11.4 \%$. Misirlioglu et al. found $2.9 \%$ of IO prevalence using CBCT. ${ }^{1}$ A study on CBCT images of a Turkish population indicated 26.9\% IO. ${ }^{15}$ Another study detected IO in $16.7 \%$ of CBCT scans of Egyptians. ${ }^{16}$ Another study on panoramic radiographs found IO in $2.4 \%$ of patients in a Croatian subpopulation. ${ }^{17}$ Ledesma-Montes et al. found IO in 5.6\% of the intraoral radiographs of a Mexican population. ${ }^{18}$ Study findings can vary due to racial differences ${ }^{15}$ and different inclusion and exclusion criteria. Our study included only the scans of the mandible, which is the most common site for IO. ${ }^{6,15,18}$ Moreover, IO prevalence can be lower in studies using panoramic radiographs because of image superimpositions that 
hide smaller and less obvious osteosclerotic areas. In 2013, using panoramic radiographs, Moshfeghi et al. ${ }^{19}$ reported 9.6\% IO prevalence in an Iranian subpopulation. In 2006, Imanimoghadam and Eatemadi-Sadjadi ${ }^{20}$ found $9 \%$ IO prevalence in another Iranian subpopulation, also by panoramic radiographs. In both studies, lower IO prevalence is caused by panoramic radiographs. CBCT allows studying structures without superimposition and could therefore diagnose small osteosclerotic areas.

We found that IO prevalence was not significantly different regarding age group or gender. Studies of Chen et al. also found no gender differences ${ }^{12}$ and several other studies had similar results ${ }^{1,4,7,12}$, whereas others reported that IO prevalence varied for age groups. ${ }^{19,20}$ Therefore, the correlation between age and IO is unclear since the patients could age between when the IO starts and when the radiographs are taken. Our study corroborates with the study of Tolentino et al. ${ }^{21}$, in which IO is prevalent in the mandibular molar region. Other studies also had similar results ${ }^{19,22}$, whereas Avramidou et al. ${ }^{23}$ reported that IO is prevalent in the posterior mandible.

In our study, most lesions were located in edentulous areas of the jaw. Similar to the studies of Imanimoghaddam and Eatemadi-Sadjadi ${ }^{20}$ and Miloglu et al. ${ }^{2}$, most lesions in the dentulous area were not associated with teeth. Sisman et al. ${ }^{4}$ claimed that, in their study, most lesions were associated with tooth apices because of occlusal imbalance.

One of this study's limitations was the relative lack of racial diversity in the studied population. However, comparing these findings with those of other studies can explain the ethnic differences in IO prevalence.

\section{CONCLUSION}

Idiopathic osteosclerosis prevalence was $11.4 \%$ in the studied population and was not statistically different between age groups or sexes. Most lesions were found in the mandibular molar region.

\section{FUNDING}

This study was financially supported by Isfahan University of Medical Sciences (\#383938). The funder did not participate in the study design, data collection and analysis, decision to publish, or preparation of the manuscript.

\section{REFERENCES}

1. Misirlioglu M, Nalcaci R, Adisen MZ, Yilmaz S. The evaluation of idiopathic osteosclerosis on panoramic radiographs with an investigation of lesion's relationship with mandibular canal by using cross-sectional cone-beam computed tomography images. J Oral Maxillofac Radiol. 2013;1(2):48-54. Doi: https://doi.org/10.4103/2321-3841.120108

2. Miloglu O, Yalcin E, Buyukkurt MC, Acemoglu H. The frequency and characteristics of idiopathic osteosclerosis and condensing osteitis lesions in a Turkish patient population. Med Oral Patol Oral Cir Bucal. 2009;14(12):e640-5. Doi: https://doi.org/10.4317/medoral.14.e640

3. White SC, Pharoah MJ. Oral radiology: principles and interpretation. 7 th ed. Amsterdam: Elsevier Health Sciences; 2014.

4. Sisman Y, Ertas ET, Ertas H, Sekerci AE. The frequency and distribution of idiopathic osteosclerosis of the jaw. Eur J Dent. 2011;5(4):409-14.

5. Araki M, Hashimoto K, Kawashima S, Matsumoto K, Akiyama Y. Radiographic features of enostosis determined with limited cone-beam computed tomography in comparison with rotational panoramic radiography. Oral Radiol. 2006;22(1):27-33. Doi: https://doi.org/10.1007/s11282-006-0044-9

6. Gamba TO, Maciel NAP, Rados PV, Silveira HLD, Arús NA, Flores IL. The imaging role for diagnosis of idiopathic osteosclerosis: a retrospective approach based on records of 33,550 cases. Clin Oral Investig. 2021;25(4):1755-65. Doi: https://doi.org/10.1007/s00784-020-03477-0

7. Halse A, Molven O. Idiopathic osteosclerosis of the jaws followed through a period of 20-27 years. Int Endod J. 2002;35(9):747-51. Doi: https://doi.org/10.1046/j. 1365-2591.2002.00561.x 
8. Yusof M, Dasor MM, Ariffin F, Reduwan NH, Kamil W, Mah MC. Idiopathic osteosclerosis mimicry of a tooth: case report. Aust DentJ. 2020;65(4):308-12. Doi: https://doi.org/10.1111/adj.12756

9. McDonnell D. Dense bone island: a review of 107 patients. Oral Surg Oral Med Oral Pathol. 1993;76(1):124-8. Doi: https://doi. org/10.1016/oo30-4220(93)90307-p

10. Kaffe I, Rozen P, Horowitz I. The significance of idiopathic osteosclerosis found in panoramic radiographs of sporadic colorectal neoplasia patients and their relatives. Oral Surg Oral Med Oral Pathol. 1992;74(3):366-70. Doi: https://doi. org/10.1016/0030-4220(92)90077-4

11. Wood NK, Goaz PW. Differential diagnosis of oral lesions. 3rd ed. St. Louis: Mosby; 1985.

12. Chen CH, Wang CK, Lin LM, Huang YD, Geist JR, Chen YK. Retrospective comparison of the frequency, distribution, and radiographic features of osteosclerosis of the jaws between Taiwanese and American cohorts using cone-beam computed tomography. Oral Radiol. 2014;30(1):53-63. Doi: https://doi. org/10.1007/s11282-013-0139-z

13. Jindal DG, Jindal V. Idiopathic osteosclerosis: a case report of rare complication with unusual presentation and review. Int J Oral Maxillofac Pathol. 2011;3(1):48-50.

14. Rheem S, Nielsen IL, Oberoi S. Incidental findings in the maxillofacial region identified on cone-beam computed tomography scans. J Orthod Res. 2013;1(1):33-39.

15. Demir A, Pekiner FN. Idiopathic osteosclerosis of the jaws in Turkish subpopulation: cone-beam computed tomography findings. Clin Exp Health Sci. 2019;9(2):117-23. Doi: https:// doi.org/10.33808/clinexphealthsci.563958

16. Zayet MK, Hassan AA. Assessment of idiopathic osteosclerosis in the jaws of the Egyptian population using cone beam computed tomography. Egypt Dent J. 2019;65(2 Oral Medi- cine, X-Ray, Oral Biology \& Oral Pathology):1397-401. Doi: https://doi.org/10.21608/edj.2019.72564

17. Verzak Ž, Ćelap B, Modrić VE, Sorić P, Karlović Z. The prevalence of idiopathic osteosclerosis and condensing osteitis in Zagreb population. Acta Clin Croat. 2012;51(4):573-7.

18. Ledesma-Montes C, Jiménez-Farfán MD, Hernández-Guerrero JC. Idiopathic osteosclerosis in the maxillomandibular area. Radiol Med. 2019;124(1):27-33. Doi: https://doi. org/10.1007/s11547-018-0944-x

19. Moshfeghi M, Azimi F, Anvari M. Radiologic assessment and frequency of idiopathic osteosclerosis of jawbones: an interpopulation comparison. Acta Radiol. 2014;55(10):1239-44. Doi: https://doi.org/10.1177/0284185113515210

20. ImaniMoghaddam M, Eatemadi-Sadjadi M. Radiographic evaluation of idiopathic osteosclerosis in patients referring to Mashhad Dental School from November 2002 to May 2004 J Shaheed Sadoughi Univ Med Sci. 2006;14(2):61-7.

21. Tolentino ES, Gusmão PHC, Cardia GS, Tolentino LS, Iwaki LCV, Amoroso-Silva PA. Idiopathic osteosclerosis of the jaw in a Brazilian population: a retrospective study. Acta Stomatol Croat. 2014;48(3):183-92. Doi: https://doi.org/10.15644/ $\operatorname{asc} 48 / 3 / 2$

22. Yonetsu K, Yuasa K, Kanda S. Idiopathic osteosclerosis of the jaws: panoramic radiographic and computed tomographic findings. Oral Surg Oral Med Oral Pathol Oral Radiol Endod. 1997;83(4):517-21. Doi: https://doi.org/10.1016/s10792104(97)90156-6

23. Avramidou FM, Markou E, Lambrianidis T. Cross-sectional study of the radiographic appearance of radiopaque lesions of the jawbones in a sample of Greek dental patients. Oral Surg Oral Med Oral Pathol Oral Radiol Endod. 2008;106(3):e3843. Doi: https://doi.org/10.1016/j.tripleo.2008.04.020 